\title{
Evaluation of the Toxic Health Hazards in Female Nurses Chronically Exposed to Anaesthetic Gases
}

\author{
Heba M. Halawa, Gihan B. Azab', Khaled M. Maghawry², and Lamiaa A Adel3
}

${ }^{1}$ Forensic Medicine and Clinical Toxicology Department
${ }^{2}$ Anaesthesia Department
${ }^{3}$ Medical Microbiology and Immunology Department
Faculty of Medicine, Ain Shams University, Cairo, Egypt.

\begin{abstract}
Background: Volatile anaesthetics are the major pollutants in operating and recovery rooms of hospitals; where the health care personnel are exposed. Serious health effects may result from chronic exposure to low levels of anaesthetic gases inhalation. Aim of The study: The study was carried out to investigate the possible hepatic, renal, haematological and immune parameters alterations in a group of workers chronically exposed to volatile anaesthetic gases compared to a non-exposed control group. Subjects and Methods: Twenty-two operating room female nurses were recruited. The control group consisted of twenty-two non-exposed similar for gender and age. Each subject examined for Hepatic function: [levels of liver transaminases (Aspartate Aminotransferase (AST), alanine aminotransferase (ALT), Gamma-glutamyltransferase (GGT) and total Bilirubin]; Kidney function: [Blood urea nitrogen (BUN), serum creatinine]; Haematological profile [complete blood count (CBC)] and Immune phenotyping of peripheral blood lymphocytes measured by flow cytometry. Results: The exposed group showed an increased prevalence of headache, asthenia, gastritis, mouth herpes, allergic reactions, rhinitis, hypertension, arrhythmia, menstrual disorders, abortion, and infertility compared to control group. The hepatic and kidney function markers were highly significantly increased in exposed group compared to control. In addition, a statistically significant decrease in total white blood cells count (WBCs), Neutrophils percentage and a significant increase in lymphocyte percentage were found compared to control group. Furthermore, Cytotoxic T cell (CD8+/CD4-) and natural killer cells (NK) (CD19-/CD56+) percentages increased significantly, While percentages of T helper (CD8-/CD4+) cells and B lymphocytes (CD19+/CD 56- ) significantly decreased compared to control group. There were non- significant difference in red blood cells count (RBC), haemoglobin, and platelet count. In conclusion female nurses chronically exposed to low level waste anaesthetic gases developed hepatic, renal, haematological and immune parameters alterations.
\end{abstract}

\section{Introduction}

$\mathrm{H}$ ealth workers are occupationally exposed to a variety of biological, physical and /or chemical factors. In operating and recovery rooms of hospitals, volatile anaesthetics are the major pollutants, where the subjects are exposed to low doses, for long periods of time (Gwak et al., 2011).

Anaesthetic gases contaminate the operating room due to anesthetic techniques as: induction of general anesthesia by mask, poorly fitting face mask, drop of liquid anesthetic during filling vaporizer, inaccurately underinflated endotracheal tube or laryngeal mask and flushing anesthesia circuit of residual gases. In addition, anesthesia machine delivery system and scavenging system play a role as maladjustment of hospital system vacuum or leaks (high-pressure hoses, nitrous oxide tank mounting, carbon dioxide absorbent canisters, low-pressure circuit) (Pothmann et al., 1991 and Yasny and White, 2012). Moreover, the exposure often exceeds set safety limits, especially in the case of paediatric anaesthesia (Raj et al., 2003). Furthermore, Waste anesthetic gases are also distributed in the exhaled air of patients recovering from anesthesia in recovery room (Li et al., 2002). The most commonly used inhaled anesthetic agents include two different classes of chemicals: nitrous oxide and volatile halogenated agents as halothane, methoxyflurane, enflurane, isoflurane, desflurane and sevoflurane. Nitrous oxide is supplied in a gas form. The halogenated agents are supplied as a liquid, which is then vaporized by the anesthesia machine into a gaseous state prior to its delivery to the patient (Shiraishi and Ikeda, 1990). 
Previously, several epidemiological studies stated that serious health effects may result from chronic exposure to low levels of anaesthetic gases inhalation (Burm, 2003, Nilsson et al., 2005 and Sahin et al., 2011). The currently used volatile anaesthetics are degraded into potentially toxic products, that may cause hepatotoxicity, nephrotoxicity, haematological changes (Caciari et al., 2013), increased prevalence of deaths from pancreatic, lymphoid and reticularendothelial malignancies (Guirguis et al., 1990), peripheral neuropathy(Biró and Tompa, 2013), multiple sclerosis (Landtblom et al., 2006), impairment of fertility, spontaneous abortion and congenital defects (Shirangi et al., 2009 and Teschke et al.,2011).

Although volatile anesthetics have been used for more than a century, their mechanisms of toxicity remain poorly understood, so it is a hot topic of research (Gross and Stern, 2014). Many studies supported the existence of oxidative DNA damages in lymphocytes of subjects exposed to nitrous oxide, halothane and isoflurane (Baysal et al., 2009, Izdes et al., 2010 and Wrońska-Nofer et al., 2012). In addition, previous experimental studies have unveiled the effect of anaesthetic gases on various immune parameters (Puig et al., 2002 and Colucci et al., 2003). In vitro exposure of human lymphocytes to anaesthetic gases such as halothane, isoflurane, enflurane and nitrous oxide decreased immune cell functions in a dosedependent manner (Welch, 1984 and Woods and Griffiths, 1986). In anaesthetised patients during the postoperative period, Suppression of immune defence has been frequently reported. However, the results are transient, both inhaled and intravenous anaesthesia were given, and immune suppression may be a combined effect of surgery stress and anaesthesia (Inada et al.,2004; Ahlers et al., 2008 and Liu et al., 2011).

Many studies have investigated the immunological status of health workers chronically exposed to volatile anaesthetics in operating theatres (Bargellini et al., 2001, Casale et al., 2013 and Biró and Tompa, 2013). Indeed, studies are not easily comparable due to the heterogeneity of exposed groups, considerable differences in gas type and levels, a great variability in immune parameters examined and the methodology of the studies. Many aspects of the immune response have been evaluated with contradictory results, some studies have not found any changes in the investigated immune parameters (Karakaya et al., 1992) and both inhibition and stimulation have been reported depending on the cell type or function (Urner et al., 2011). In addition, Confounding factors related to lifestyles, namely smoking and alcohol consumption altered the measured immune parameters (Biró and Tompa, 2013).

Therefore, the aim of this study is to investigate the possible hepatic, renal, haematological and immune parameters alteration in a group of workers chronically exposed to anaesthetic gases compared to a control group of non-exposed subjects.

\section{Materials and Methods}

\section{Subjects}

The study was carried out on twenty-two operating room female nurses, who chronically exposed to waste anaesthetic gases without protective measures. Their results were compared to twenty-two healthy controls, not occupationally exposed to known substances, at Ain Shams University Hospitals. After institutional and ethical committee approval a preliminary meeting was organised to explain the purpose of the study, to answer questionnaire questions and informed consent from all exposed and control subjects were taken.

The questionnaire included information on age, smoking habit, alcohol consumption, type of anaesthetic gases and duration of exposure, exposure to $\mathrm{X}$-rays, pre-occupational or current history of liver, renal, haematological, neurological, cardiovascular, reproductive and immunological disorders and intake of medications and contraceptive pills. The anaesthetic gases mainly used in the operating rooms were: (sevoflurane, isoflurane mixed with oxygen), in addition they were previously exposed to halothane and nitrous oxide, in past years.

In order to avoid the influence of the confounding factors, which could alter the immune parameters, all nurses are female and those older than 50 years were excluded (Peric et al., 1994 and Marttila et al., 2013). Moreover, subjects were excluded if they were active smokers (Biró and Tompa, 2013), exposed to X-rays (Caciari et al., 2012), alcohol drinkers (Romeo et al., 2007 and Burnham et al., 2013) or having pre-employment history of hepatic, renal, blood diseases or recent infection.

\section{Laboratory parameters}

A $10 \mathrm{ml}$ venous blood sample was taken from each nurse and control subjects. The samples were processed to assess:

\section{Hepatic parameters}

Levels of liver transaminases (aspartate aminotransferase (AST), alanine aminotransferase (ALT), gamma-glutamyltransferase (GGT) were determined by colorimetric method according to Frankel and Gradwohl (1970) and total bilirubin was measured according to Suber (1994).

\section{Kidney parameters}

Blood urea nitrogen (BUN) and serum ceatinine were measured by colorimetric method according to Lawrence and Robert (1993). The assay kits were purchased from Alkane Company.

\section{Haematological profile}

Complete Blood Count (CBC) using coulter counter model M450 (coulter Electronics Ltd, Australia).

\section{Immune phenotyping of peripheral blood lymphocytes by flow cytometry}

$1 \mathrm{ml}$ blood was mixed with EDTA. $100 \mu \mathrm{l}$ of the blood sample was taken and divided in two Wassermann tubes, $50 \mu 1$ in each, the tubes were incubated in dark at room temperature for 20 minutes with $5 \mu$ of 
monoclonal antibodies against surface antigens, and these monoclonal antibodies were labelled with Fluorescein Isothiocyanate (FITC) and Phycoerythrin (PE). The erythrocytes were removed by Lysing solution (Ammonium chloride based) incubated for 510 minutes in dark at room temperature. After washing with Phosphate Buffered Saline (PBS), a suspension with $500 \mu \mathrm{l}$ of PBS was made and samples were analyzed within 4 hours after labelling. The studied antigens were: Helper $\mathrm{T}$ cells $(\mathrm{CD} 4+)$, cytotoxic $\mathrm{T}$ cells (CD8+), Natural killer (NK) cells (CD 56+) and B lymphocytes (CD19+). The following monoclonal antibody combinations were used: in the first tube, CD4- FITC / CD8-PE; and in the second tube CD19FITC / CD56. Helper T cells were characterized by CD8- /CD4+ phenotype, cytotoxic $T$ cells by CD8+/CD4- phenotype, NK cells as CD19-/CD56+ phenotype and $\mathrm{B}$ lymphocytes were characterized as CD19+/CD 56- cells. Phenotypes are expressed as percentage of positive cells of a given lymphocyte subpopulation. All analysis was performed on a COULTER EPICS XL-MCL Flow Cytometry SYSTEM II Software (COULTER CORPORATION, Miami, Fl, USA).

\section{Statistical analysis}

Using PASS (power and sample size), it was calculated that a sample size of twenty-two per group will achieve $80 \%$ power to detect a mean difference between the exposed and control group with a significance level (alpha) of 0.05 using a two-sided two-sample t-test. The statistical analysis was performed using a standard SPSS (Statistical Package for Social Science) software package, version 17 (Chicago, IL). Data were expressed as (mean \pm SD), numbers (\%). Student's t-test was used to analyze the parametric data, and discrete variables were analyzed using chi-square test $\left(\chi^{2}\right)$, with $\mathrm{p}<0.05$ considered statistically significant (Taylor, 1990).

\section{Results}

Age of exposed nurses ranged from 31 to 40 years with mean $35.3 \pm 4.6$ years and the duration of exposure to anaesthetic gases ranged from 8 to 12 years with mean $9.8 \pm 3.1$ years. The control group was similar for gender and age.

After analysis of the questionnaire, an increased prevalence of headache $(54.5 \%)$, asthenia (41\%), gastritis $(45.5 \%)$, mouth herpes $(22.7 \%)$, allergic reactions $(9.1 \%)$, rhinitis $(45.5 \%)$, hypertension $(18.1 \%)$, arrhythmias $(31.8 \%)$, menstrual disorders (45.4\%), abortion (18.2\%) and infertility (13.6\%) appears in exposed groups compared to controls Table (1).

The blood levels of AST, ALT, GGT, and total Bilirubin, BUN, and creatinine were highly significantly increased in exposed group compared with the control group (Table 2 and 3 ).

Regarding $\mathrm{CBC}$, there were non- significant difference in RBC count, $\mathrm{Hb}$ level, and platelet count in exposed compared to control group. While, a very highly significant decrease in total WBCs count, significant decrease in neutrophils percentage and significant increase in lymphocyte percentage was found in exposed group compared to control group as shown in Table (4).

As regard lymphocytes differential count: Cytotoxic T cell (CD8+/CD4-) percentage significantly increased and NK cells (CD19-/CD56+) percentage very highly significantly increased, while percentages of T helper (CD8- /CD4+) cells and B lymphocytes ( CD19+/CD 56-) significantly decreased in exposed group compared to control group as shown in (Table 5) and (figures $1,2,3$ ).

Table 1: Chi-square test comparing some health disorders in the control and exposed groups.

\begin{tabular}{|l|c|c|c|}
\hline & $\begin{array}{c}\text { Control Group } \\
\mathbf{n}(\%)\end{array}$ & $\begin{array}{c}\text { Exposed Group } \\
\mathbf{n}(\mathbf{\%})\end{array}$ & $\mathbf{p}$ \\
\hline Headache & $3(13.6 \%)$ & $12(54.5 \%)^{* *}$ & $<0.01$ \\
\hline Asthenia & $2(9.1 \%)$ & $9(41 \%)^{*}$ & $<0.05$ \\
\hline Gastritis & $1(4.5 \%)$ & $10(45.5 \%)^{*}$ & $<0.05$ \\
\hline Mouth herpes & $1(4.5 \%)$ & $5(22.7 \%)^{* *}$ & $<0.01$ \\
\hline Allergic reactions & $0 \%$ & $2(9.1 \%)^{*}$ & $<0.05$ \\
\hline Rhinitis & $2(9.1 \%)$ & $10(45.5 \%)^{*}$ & $<0.05$ \\
\hline Hypertension & $3(13.6 \%)$ & $4(18.1 \%)$ & $>0.05$ \\
\hline Arrhythmia & $1(4.5 \%)$ & $7(31.8 \%)^{*}$ & $<0.05$ \\
\hline Menstrual disorders & $1(4.5 \%)$ & $10(45.4 \%)^{* * *}$ & $<0.001$ \\
\hline Abortion & $2(9.1 \%)$ & $4(18.2 \%)^{* *}$ & $<0.01$ \\
\hline Infertility & $0 \%$ & $3(13.6 \%)^{*}$ & $<0.05$ \\
\hline
\end{tabular}


Table 2: Student's $t$-test comparing hepatic parameters [aspartate aminotransferase (AST), alanine aminotransferase (ALT), gamma-glutamyltransferase (GGT), and total Bilirubin] between the control and exposed groups.

\begin{tabular}{|l|c|c|c|}
\hline \multicolumn{1}{|c|}{ Parameter } & Control Group $(\mathbf{n = 2 2})$ & Exposed Group $(\mathbf{n}=\mathbf{2 2})$ & $\mathrm{P}$ \\
\hline AST IU/L $($ Mean $\pm \mathrm{SD})$ & $21.0 \pm 9.1$ & $37.5 \pm 16.4^{* * *}$ & $<0.001$ \\
\hline ALT IU/L $($ Mean $\pm \mathrm{SD})$ & $28.1 \pm 7.6$ & $41.3 \pm 15.9 * * *$ & $<0.001$ \\
\hline GGT IU/L (Mean $\pm \mathrm{SD})$ & $26.75 \pm 21.30$ & $38.4 \pm 20.11^{* * *}$ & $<0.001$ \\
\hline Total Billirubin $\mathrm{m} / \mathrm{dl}(\mathrm{Mean} \pm \mathrm{SD})$ & $0.7 \pm 0.14$ & $0.9 \pm 0.21^{*}$ & $<0.05$ \\
\hline
\end{tabular}

Table 3: Student's $t$-test comparing kidney parameters [blood urea nitrogen (BUN) and creatinine] between the control and exposed groups.

\begin{tabular}{|c|c|c|c|}
\hline \multicolumn{1}{|c|}{ Parameter } & Control Group $(\mathbf{n = 2 2})$ & Exposed Group $(\mathbf{n = 2 2})$ & $\mathrm{P}$ \\
\hline BUN mg/dl (Mean \pm SD) & $20.6 \pm 8.1$ & $35.9 \pm 14.7^{* * *}$ & $<0.001$ \\
\hline Creatinine mg/dl (Mean \pm SD) & $0.6 \pm 0.4$ & $1.1 \pm 0.3^{*}$ & $<0.05$ \\
\hline
\end{tabular}

$* p<0.05=$ statistically significant $; * * *<0.001=$ very highly significant; $S D=$ standard deviation.

Table 4: Student's $t$-test comparing haematological parameters [red blood cells count (RBCs), Haemoglobin (Hb), platelets count, total white blood cells count (WBCs), neutrophils percentage and lymphocytes percentage] between the control and exposed groups.

\begin{tabular}{|l|c|c|c|}
\hline \multicolumn{1}{|c|}{ Parameter } & Control Group (n=22) & Exposed Group (n=22) & P \\
\hline $\mathrm{RBC} / \mathrm{mm}^{3}($ Mean $\pm \mathrm{SD})$ & $5.1 \pm 0.7$ & $4.9 \pm 0.9$ & $>0.05$ \\
\hline $\mathrm{Hb}$ g/dl $($ Mean $\pm \mathrm{SD})$ & $12.0 \pm 0.92$ & $11.5 \pm 1.22$ & $>0.05$ \\
\hline Platelets $/ \mathrm{mm}^{3}(\mathrm{Mean} \pm \mathrm{SD})$ & $313.54 \pm 17.6$ & $306.77 \pm 16.25$ & $>0.05$ \\
\hline WBC/mm $($ Mean $\pm \mathrm{SD})$ & $8.6 \pm 2.3$ & $6.5 \pm 1.6^{* * *}$ & $<0.001$ \\
\hline Neutrophils\% $($ Mean $\pm \mathrm{SD})$ & $62.0 \pm 3.85$ & $52.3 \pm 7.1^{*}$ & $<0.05$ \\
\hline Lymphocytes\% (Mean $\pm \mathrm{SD})$ & $29.85 \pm 7.95$ & $35.49 \pm 8.18^{*}$ & $<0.05$ \\
\hline
\end{tabular}

${ }^{*} p<0.05=$ statistically significant $; * p<0.01=$ highly significant; $* * * p<0.001=$ very highly significant; $p>0.05=$ statistically non- significant; $S D=$ standard deviation.

Table 5: Student's $t$ - test comparing percentages of total lymphocytes and lymphocyte subpopulations [T helper (CD8-/CD4+), cytotoxic T cells (CD8+/CD4-), the natural killer (NK) (CD19-/CD56+) and B lymphocytes (CD19+/CD 56- )] between the control and exposed groups.

\begin{tabular}{|l|c|c|c|}
\hline \multicolumn{1}{|c|}{ Parameter } & Control Group (n=22) & Exposed Group (n=22) & P \\
\hline Total lymphocytes \% (Mean \pm SD) & $29.85 \pm 7.95$ & $35.49 \pm 8.18^{*}$ & $<0.05$ \\
\hline Helper T cells (CD4) \% (Mean \pm SD) & $38.63 \pm 2.12$ & $30.32 \pm 3.05^{*}$ & $<0.05$ \\
\hline Cytotoxic T cells (CD8+)\% (Mean \pm SD) & $33.64 \pm 1.8$ & $40.5 \pm 4.15^{*}$ & $<0.05$ \\
\hline Natural killer (NK) cells (CD 56+)\% (Mean \pm SD) & $12.64 \pm 0.95$ & $18.91 \pm 2.29^{* * *}$ & $<0.001$ \\
\hline B lymphocytes (CD19+)\% (Mean \pm SD) & $5.93 \pm 0.31$ & $4.96 \pm 0.48^{*}$ & $<0.05$ \\
\hline
\end{tabular}

${ }^{*} p<0.05=$ statistically significant; $* * * p<0.001=$ very highly significant; $S D=$ standard deviation. 


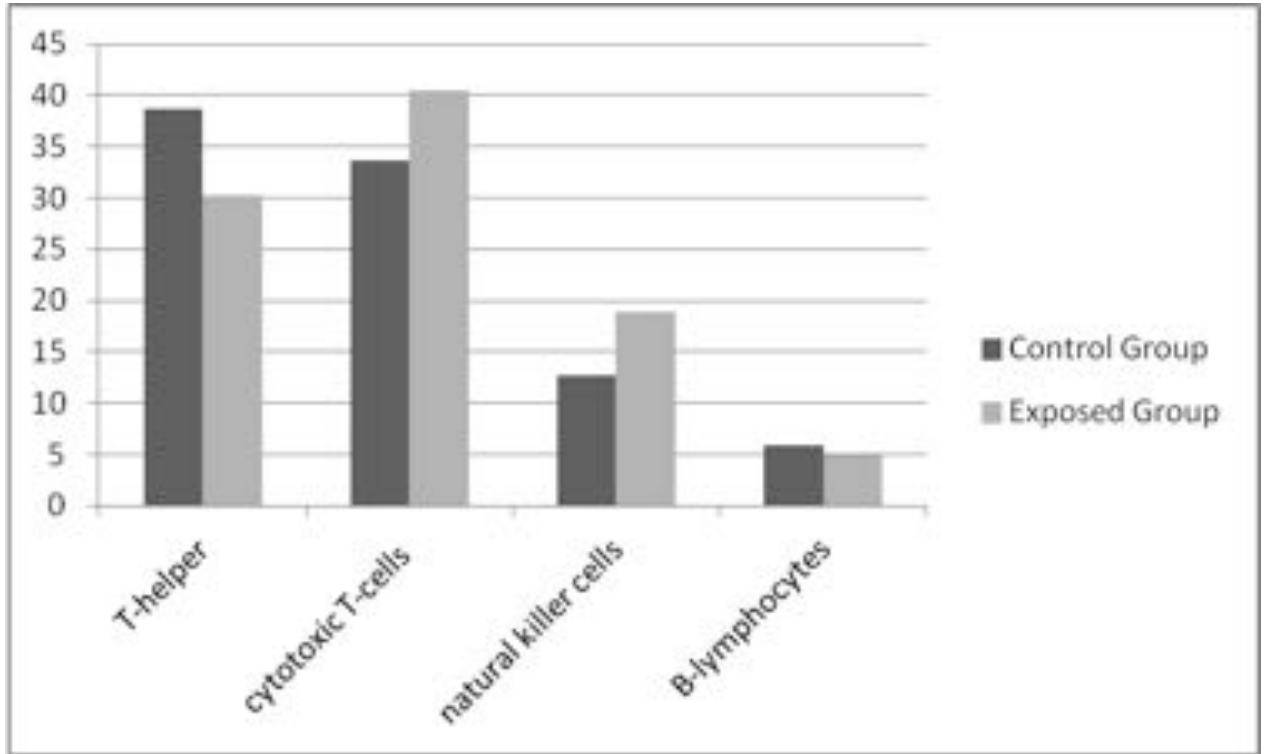

Figure 1: mean percentage of $T$-helper cells, cytotoxic $T$ cells, natural killer cells and B lymphocytes between the control and exposed groups.

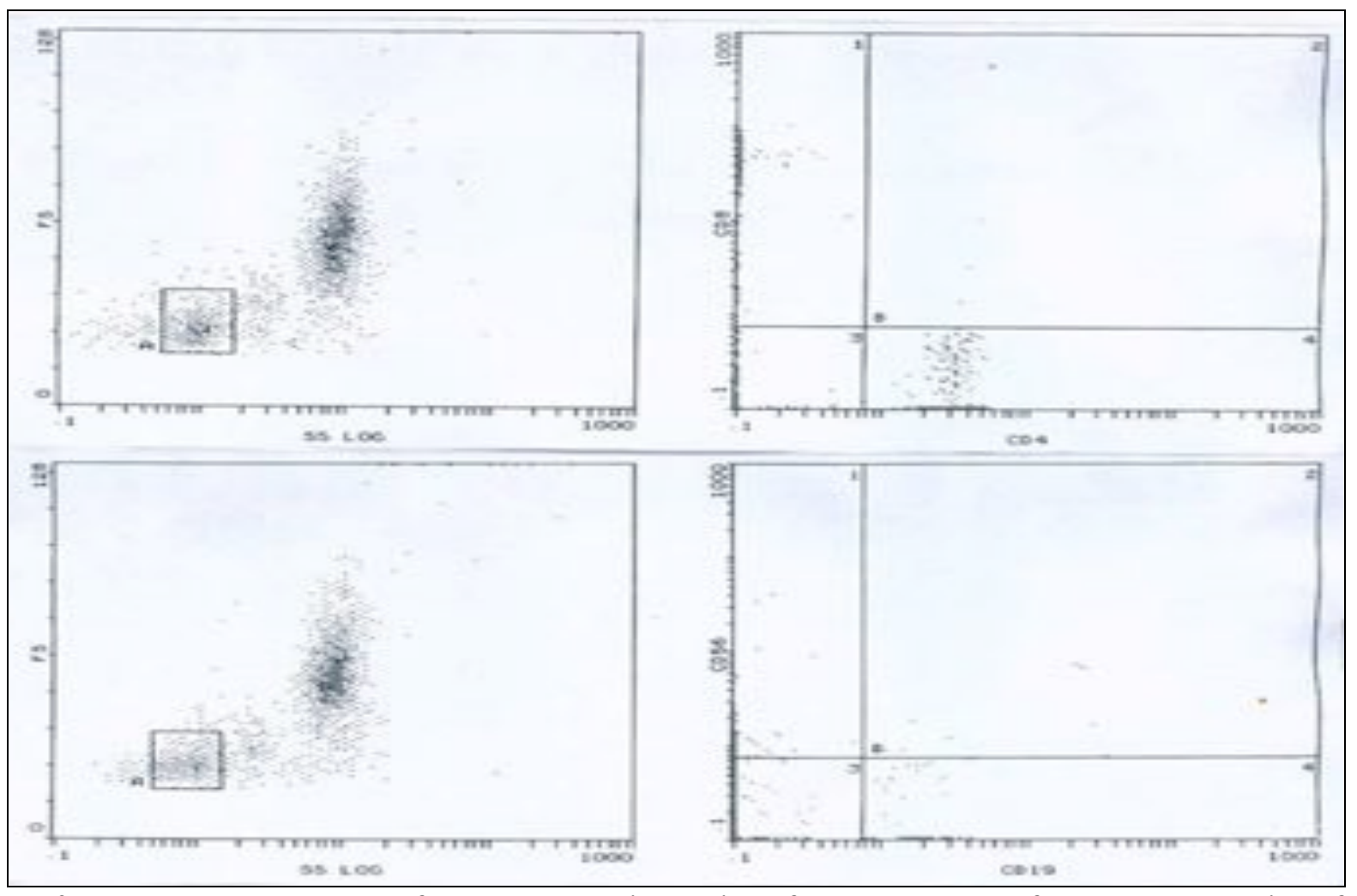

Figure 2: Flow cytometry report of a control showing gating of the lymphocytes followed by detection of the percentage of different type of cells; T cytotoxic cell ( CD8+, CD4-) 36.0\%, T helper cell (CD8-, CD4+) 41.4 \%, Natural killer cell ( CD 56+,CD 19-) 12.4\% and B lymphocyte (CD 56-, CD 19+) 7.42 \%. 


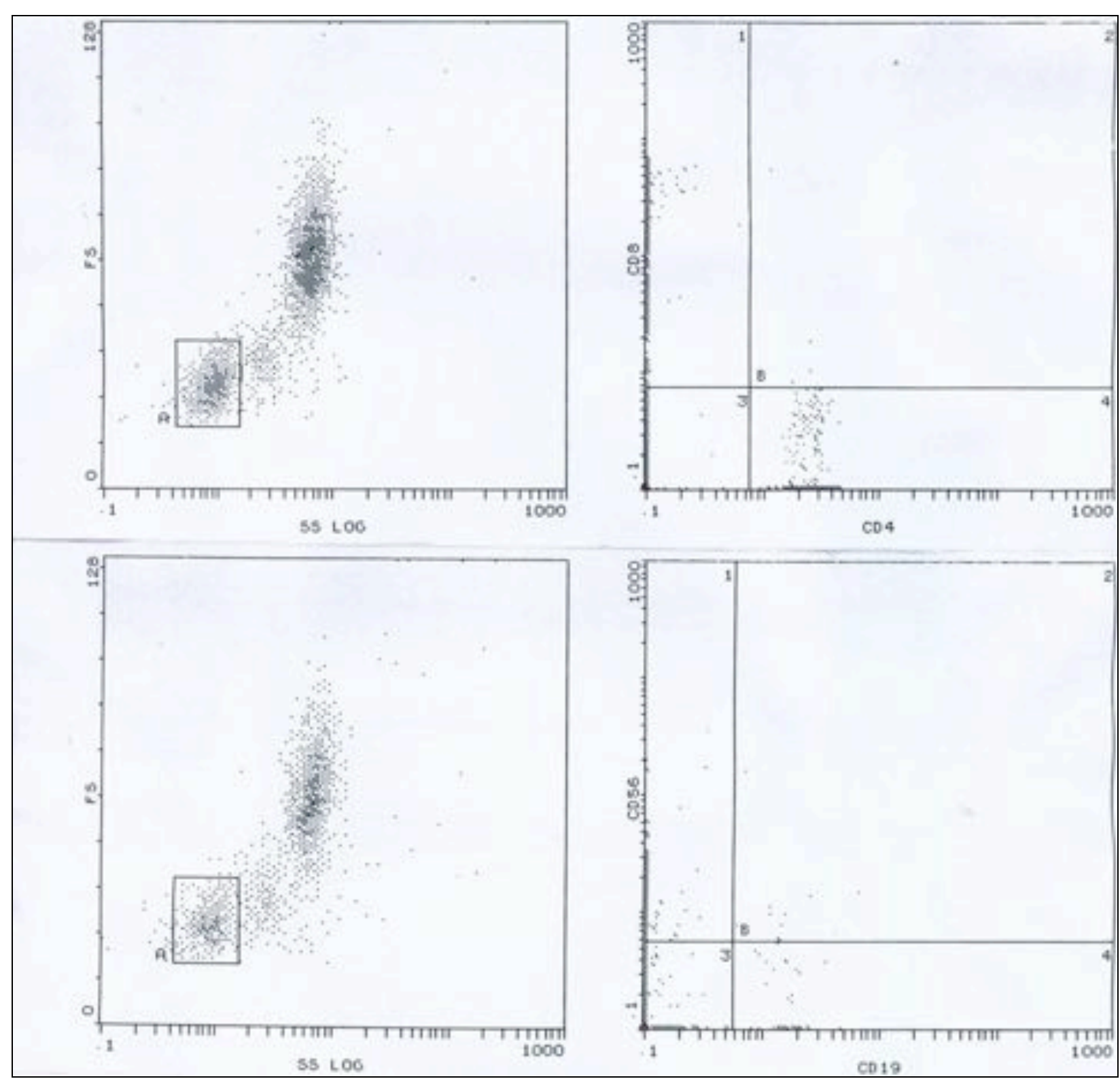

Figure 3: Flow cytometry report of anaesthetic exposed case showing gating of the lymphocytes followed by detection of the percentage of different type of cells; $T$ cytotoxic cell (CD8+, CD4-) 39.9\%, $T$ helper cell (CD8-, CD4+) 27.9\%, Natural killer cell (CD 56+,CD 19-) $32.4 \%$ and B lymphocyte (CD 56-, CD 19+) $3.66 \%$.

\section{Discussion}

After analysing the questionnaire, the exposed personnel showed significant increase in prevalence of headaches, asthenia, gastritis, mouth herpes, allergic reactions, rhinitis, hypertension, arrhythmia, menstrual disorders, abortion and infertility compared to the control group. These results were in agreement with Tannenbaum and Goldberg (1985), Talamanca (2000) and Patelarou et al. (2012). Previously, a study of Lucchini et al. (1996) proved that chronic exposure to low levels of anaesthetic gases causes an impairment of neurobehavioral performance, which was explained by interference with the dopaminergic system. Generally volatile anaesthetics cause formation of reactive oxygen species that could be involved in pathogenesis of reproductive, cardiovascular, neurological, immune and pulmonary toxicities (Kovacic and Somanathan, 2011).
The present study showed altered liver and kidney parameters in exposed nurses compared with controls. These results were in agreement with previous experimental studies where the presence of hepatotoxicity and nephrotoxicity by sevoflurane and isoflurane has been detected in animals (Gonsowski et al., 1994, Kandel et al., 1995 and Arici et al., 2013). On the other hand, Elena et al. (2003) observed that sevoflurane-treated animals showed no evidence of histological changes or alteration in hepatic or renal function. Other studies on patients and health care workers exposed to different anaesthetic gases, statistically significant increases in AST, ALT, GGT, total bilirubin and serum creatinine has been demonstrated (Sahin et al., 2011, Toprak et al., 2012, Caciari et al., 2013 and Casale et al., 2013).

The liver is one of the main body organs performing drug metabolism. Hepatic cells, during their 
metabolic functions, continuously produce reactive oxygen species. They are reduced to other forms of oxygen by mitochondria; this process may be deficient in non healthy liver or when the liver is exposed to an extraordinary unwanted burden of toxins (Gottschalket et al., 2012). This oxidant damage would disturb many parts of the cell structure in hepatocytes leading to apoptosis (Malhi and Gores, 2008). During the recent years, it has been demonstrated in a great number of studies that most current anaesthetic volatile agents (like halothane, isoflurane, desflurane and sevoflurane), have been labelled as having apoptotic properties in animal studies, exerting their effect in a dose-dependent manner (Dabbagh and Rajaei , 2013).

Furthermore, for unknown reasons the liver proteins altered by anaesthetic gases, seem to be seen as non-self by the immune system of the patient. This process may induce an auto-lymphocyte-mediated immune reaction against the liver (Martin, 2005). That was demonstrated previously by the presence of significantly elevated levels of lymphocytes and autoantibodies associated with hepatic injury in a group of paediatric female anaesthetists (Njoku et al., 2002).

These results are in agreement with the present study Immune-phenotyping results; that showed a highly significant decrease in total WBCs count and neutrophils percent. While a significant increase in percentages of total lymphocytes cells was observed. Percentage of cytotoxic $\mathrm{T}$ cell and NK increased significantly. While percentages of $\mathrm{T}$ helper cells and B lymphocytes significantly decreased in exposed group compared to control group.

The role of the cytotoxic $\mathrm{T}$ cell is to monitor all the cells of the body, ready to destroy any cell considered a threat to the integrity of the host; for example, cytotoxic $\mathrm{T}$ cells kill virally infected cells, preventing them from being the source of more viral pathogen. Moreover, they are thought to provide some degree of protection against spontaneous malignant tumours, by virtue of their ability to detect quantitative and qualitative antigenic differences in transformed cells (Andersen et al., 2006). As regard the role of NK cells, they are analogous to cytotoxic $\mathrm{T}$ cells as they provide rapid responses, in the absence of antibodies and major histo-compatibility complex, to virally infected cells and respond to tumour formation. This role of NK cells is critical for immune success particularly because $\mathrm{T}$ cells are unable to recognize pathogens in the absence of surface antigens. Tumour cell detection results in activation of NK cells and consequent cytokine production and release (Poggi and Zocchi , 2014).

Available literature data regarding immunotoxicityare are relatively scarce and conflicting. In accordance, Casale et al. (2013) study on exposed workers showed that the lymphocytes percentage was above the normal range and values of neutrophils granulocytes was below the normal range. In addition, Bargellini et al. (2001) study of chronic exposure to trace amounts of Nitrous oxide and Isoflurane in a group of relatively young anaesthetists, showed decrease of percentages of $\mathrm{T}$ helper lymphocytes, while neither other lymphocyte subpopulations nor cytotoxic activity of NK cells was affected by the exposure to anaesthetic gases. In Bargellini's study the observed imbalance in immune cell composition may be regarded as the result of an exposure which was not heavy, due to the scavenging systems of the theatres, and was limited to nitrous oxide and isoflurane, two of the less toxic anaesthetic gases.

Furthermore, Biró and Tompa (2013) examined the health personnel exposed to anaesthetic gases and found a significant elevation of activated cytotoxic $\mathrm{T}$ cells and the activation of lymphocytes in exposed personnel without protective measures compared to personnel with protective measures. Moreover, in anaesthetic personnel who previously exposed to very high concentrations of halothane and nitrous oxide, B lymphocytes numbers and percentages decreased significantly, $\mathrm{T}$ helper lymphocyte percentage were increased significantly and NK cells percentage decreased significantly during exposure (Peric et al.,1991). Indeed, T helper lymphocytes have a prominent action on $\mathrm{B}$ cell activation, and their depletion could be followed by a progressive suppression in B cell number and activity (Bargellini et al., 2001). On the other hand, other reports could not find any effect on lymphocyte counts (Atallah et al., 1991 and Karakaya et al., 1992). These studies and the present one, show that the exposing agent and the exposure level cause the differences in findings.

In conclusion, female nurses chronically exposed to low levels of waste anaesthetic gases developed hepatic, renal, haematological and immune parameters alterations.

It is recommended to minimise occupational exposure by usage of suitable protective measures, thus effectively preventing delayed effects on health. Further studies are needed for determining the appropriateness of periodic check-ups of immune functions and the most efficient and cost-effective ways of monitoring immune functions in health workers exposed to anaesthetic gases for detecting early changes in the immune system.

\section{References}

Ahlers O, Nachtigall I, Lenze J, et al., (2008): Intraoperative thoracic epidural anaesthesia attenuates stress-induced immune-suppression in patients undergoing major abdominal surgery. Br. J. Anaesth. 101: 781-787.

Andersen MH, Schrama D, and Thor Straten Pand Becker JC (2006): Cytotoxic T cells. J Invest Dermatol. Jan; 126(1):32-41.

Arici S, Karaman S, Dogru S, et al., (2013): Effects of isoflurane in an intoxication model: experimental study. Eur Rev Med Pharmacol Sci. Jul; 17(13):1738-43.

Atallah MM, Motawea AA, el-Chennawy FA, et al., (1991): Immunological assays following exposure to halothane in clinical usage. Eur J Anaesth. 8: 459-464.

Bargellini A, Rovesti S, Barbieri A, et al., (2001): Effects of chronic exposure to anaesthetic 
gases on some immune parameters. Sci Total Environ. 270: 149-156.

Baysal Z, Cengiz M, Ozgonul A, et al., (2009): Oxidative status and DNA damage in operating room personnel. Clin. Biochem. Feb; 42(3):189-93.

Biró A and Tompa A (2013): Life Style Factors Influencing Immunotoxic Effects Detected on Peripherial Blood Lymphocytes of Health Personnel Exposed to Anesthetic Gas. Clin Exp Pharmacol. S4: 004.

Burm AGL (2003): Occupational hazard of inhalational anaesthetics. Best Pract. Res. Clin. Anesthesiol.17, 147-161.

Burnham EL, Kovacs EJ, and Davis CS (2013): Pulmonary cytokine composition differs in the setting of alcohol use disorders and cigarette smoking. Am J Physiol Lung Cell Mol Physiol. Jun 15; 304(12):L873-82.

Caciari T, Capozzella A, Tomei F, et al., (2013): Professional exposure to anaesthetic gases in health workers: estimate of some hepatic and renal tests. Clin Ter. 164(1):e5-9

Caciari T, Capozzella A, Tomei F, et al., (2012) :Professional exposure to ionizing radiations in health workers and white blood cells. Ann Ig. Nov-Dec; 24(6):465-74.

Casale T, Caciari T, Rosati MV, et al., (2013): Anaesthetic gases and occupationally exposed workers. Environ Toxicol Pharmacol. Dec $11 ; 37(1): 267-274$.

Colucci D, Ferrero P, Ferreyra P, et al., (2003):Effects of Sevoflurane anaesthesia on the immune response and biochemical parameters in mice. Comparison between single exposure and repeated anesthesia. Rev Esp Anestesiol Reanim. Apr; 50(4):170-5.

Dabbagh A and Rajaei S (2013): The Role of Anaesthetic Drugs in Liver Apoptosis. Hepat Mon. Aug 25; 13(8).

Elena G, Amerio N, Ferrero P, et al., (2003): Effects of repetitive sevoflurane anaesthesia on immune response, select biochemical parameters and organ histology in mice. Lab Anim. Jul; 37(3):193-203.

Frankel S and Gradwohl EC (1970): Colorimetric method for determination of serum transaminases. Am. J. Clin. Pathol. 28:26-34.

Gonsowski CT, Laster MJ, Eger EI, et al., (1994): Toxicity of compound A in rats: effect of a 3hour administration. Anesthesiology. 80, 556-565.

Gottschalket S, Zwingmann C, Raymond VA, et al., (2012): Hepato-cellular apoptosis in mice is associated with early up regulation of mitochondrial glucose metabolism. Apoptosis. 17(2):143-53.

Gross AF and Stern TA (2014): Neuropsychiatric conditions associated with anaesthesia exposure. Psychosomatics. Jan-Feb; 55(1):218.

Guirguis S, Pelmear P, Roy M, et al., (1990): Health effects associated with exposure to anaesthetic gases in Ontario hospital personnel. Br. J. Ind. Med. 47, 490-497.

Gwak MS, Cao L, Li L, et al., (2011): Isoflurane preconditioning reduces oxygen-glucose deprivation-induced neuronal injury via B-cell lymphoma 2 protein. Environ. Toxicol. Pharmacol. 31, 262-265.

Inada T, Yamanouchi Y, Jomura S, et al., (2004): Effect of propofol and isoflurane anaesthesia on the immune response to surgery. Anaesthesia. Oct; 59(10):954-9.

Izdes S, Sardas S, Kadioglu E, et al., (2010): DNA damage, glutathione, and total antioxidant capacity in anaesthesia nurses. Arch Environ Occup Health. Oct-Dec; 65(4):211-7.

Kandel L, Laster MJ, Eger EI, et al., (1995): Nephrotoxicity in rats undergoing a one-hour exposure to compound A. Anesth. Analg. 81, 559-563.

Karakaya A, Tunçel N, Yücesoy B, et al., (1992): The effects of volatile anaesthetic agents on human immune system function via occupational exposure. Immuno pharmacol Immunotoxicol. 14: 251-259.

Kovacic P and Somanathan R (2011): Mechanism of Anaesthetic Toxicity, Metabolism, Reactive Oxygen Species, Oxidative Stress, and Electron Transfer. ISRN Anesthesiology Article ID 402906, 10 pages.

Landtblom AM, Tondel M, Hjalmarsson P, et al., (2006): The risk for multiple sclerosis in female nurse anaesthetists: a register based study. Occup Environ Med. Jun; 63(6):3879.

Lawrence M and Robert HC (1993): Methods of determination of blood urea nitrogen and serum creatinine, In: Tietz textbook of clinical chemistry, $2^{\text {nd }}$ edition, WB Saunders Company, London, pp.621.

Li SH, Shih HY, Yi HD, et al., (2002): Personnel exposure to waste sevoflurane and nitrous oxide during general anaesthesia with cuffed endotracheal tube. Acta Anaesthesiol.Sin. 40: 185-190.

Liu S, Wang B, Li S, et al., (2011): Immune cell populations decrease during craniotomy under general anesthesia. Anesth. Analg. 113: 572577.

Lucchini R, Placidi D, Toffoletto F, et al., (1996): Neurotoxicity in operating room personnel working with gaseous and non gaseous anaesthesia. Int Arch Occup Environ Health. 68:188-92.

Malhi H and Gores GJ (2008): Cellular and molecular mechanisms of liver injury. Gastroenterology. 134(6):1641-54.

Martin JL (2005): Volatile anaesthetics and liver injury: a clinical update or what every anaesthesiologist should know. Can. J.Anaesth. 52: 125-129.

Marttila S, Jylhävä J, Nevalainen T, et al., (2013): Transcriptional analysis reveals genderspecific changes in the aging of the human 
immune system. PLoS One. Jun 11;8 (6):e66229.

Nilsson R, Bj”ordal C, Andersson M, et al., (2005): Health risks and occupational exposure to volatile anaesthetics - a review with a systematic approach. J. Clin. Nurs. 14: 173186.

Njoku DB, Greenberg RS, Bourdi M, et al., (2002): Auto-antibodies associated with volatile anaesthetic hepatitis found in the sera of a large cohort of paediatric anaesthesiologists. Anesth. Analg. 94:243-249.

Patelarou A, Melidoniotis E, and Patelarou E (2012): The effects of exposure of health care professionals to volatile anaesthetic gases. Archives of Hellenic Medicine. : Jan/ Feb. 29 (1), p23-28.

Peric M, Petrovecki M, and Marusic M (1994): Agedependent haematological disturbances in anaesthetic personnel chronically exposed to high occupational concentrations of halothane and nitrous oxide. Anaesthesia. 49:1022-1027.

Peric M, Vranes Z, and Marusic M (1991): Immunological disturbances in anaesthetic personnel chronically exposed to high occupational concentrations of nitrous oxide and halothane. Anaesthesia. 46: 531-537.

Poggi A and Zocchi MR (2014): NK Cell Autoreactivity and Autoimmune Diseases. Front Immunol. Feb 4; 5:27.

Pothmann W, Shimada K, Goerig M, et al., (1991): Pollution of the workplace by anaesthetic gases. Causes and prevention. Anaesthesist. Jun; 40(6):339-46.

Puig NR, Ferrero P, Bay ML, et al., (2002): Effects of Sevoflurane general anaesthesia: immunological studies in mice. Int Immunopharmacol. Jan; 2(1):95-104.

Raj N, Henderson KA, Hall JE, et al., (2003): Evaluation of personal, environmental and biological exposure of paediatric anaesthetists to nitrous oxide and sevoflurane. Anaesthesia.58: 630-636.

Romeo J, Warnberg J, Nova E, et al., (2007): Changes in the Immune System after Moderate Beer Consumption. Ann Nutr Metab. 51: 359-366.

Sahin SH, Cinar SO, Paksoy I, et al., (2011): Comparison between low flow Sevoflurane anaesthesia and total intravenous anaesthesia during intermediate-duration surgery: effects on renal and hepatic toxicity. Hippokratia, 15, 69-74.

Shiraishi Yand Ikeda K (1990): Uptake and biotransformation of sevoflurane in humans: a comparative study of sevoflurane with halothane, enflurane, and isoflurane. J Clin Anesth. Nov-Dec; 2(6):381-6.

Shirangi A, Fritschi L, and Holman CD (2009): Associations of unscavenged anaesthetic gases and long working hours with preterm delivery in female veterinarians. Obstet. Gynecol. May; 113(5):1008-17.

Suber RL (1994): Clinical pathology methods for toxicology. In: Principles and methods of toxicology. Hayes AW, (ed), $3^{\text {rd }}$ ed., Raven press, New York, pp: 476-96

Talamanca FI (2000): Reproductive problems among women health care workers: Epidemiologic evidence and preventive strategies. Epidemiol Rev. 22:249-260.

Tannenbaum TN and Goldberg RJ (1985): Exposure to anaesthetic gases and reproductive outcome. A review of the epidemiologic literature. J Occup Med. 27:659-68.

Taylor JK (1990): Statistical technique for data analysis. $2^{\text {nd }}$ ed. Lewis Pub. Inc. USA. P.2530 .

Teschke K, Abanto Z, Arbour L, et al., (2011): Exposure to anaesthetic gases and congenital anomalies in off spring of female registered nurses. Am J Ind. Med. Feb; 54(2):118-27.

Toprak HI, Sahin T, Aslan S, at al., (2012): Effects of desflurane and isoflurane on hepatic and renal functions and coagulation profile during donor hepatectomy. Transplant. Proc. 44: 16351639.

Urner M, Limbach LK, Herrmann IK, et al., (2011): Fluorinated groups mediate the immunemodulatory effects of volatile anaesthetics in acute cell injury. Am. J. Respir. Cell Mol. Biol. 45:617-624.

Welch WD (1984): Effect of Enflurane, isoflurane and nitrous oxide on the microbicidal activity of human polymorphonuclear leukocytes. Anesthesiology.61:188-192.

Woods GM and Griffiths DM (1986): Reversible inhibition of natural killer cell activity by volatile anaesthetic agents in vitro. $\mathrm{Br} J$ Anesth.58:535-539.

Wrońska-Nofer T, Nofer JR, Jajte J, et al., (2012): Oxidative DNA damage and oxidative stress in subjects occupationally exposed to nitrous oxide (N2O). Mutat. Res. Mar 1; 731(1-2):5863.

Yasny JS and White J (2012): Environmental implications of anaesthetic gases. Anesth Prog. Winter 59(4):154-8. 


$$
\text { الملخص العربي }
$$

\section{تقييم المخاطر الصحية السمية الناتجة من تعرض الممرضات المهني المزمن للغازات المخدرة}

\section{هبة محمد حلاوة و جيهان بشرى عزب1 و خالد محمد مغاوري 2 لمياء عبد المنعم عادل3}

الخلفية: تعتبر غاز ات التخدير من الملوثات الرئيسية في غرف العمليات وغرف الإنعاش في المستشفيات، حيث

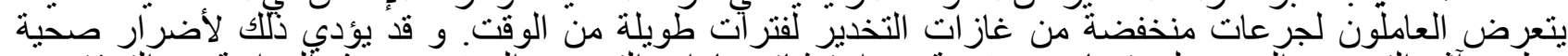

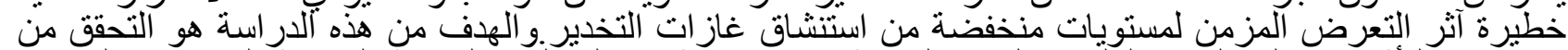

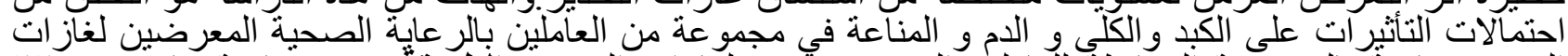

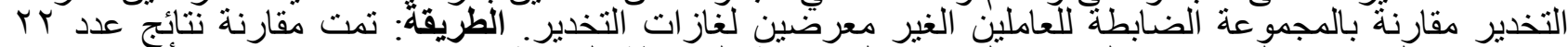

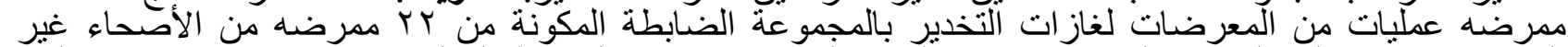

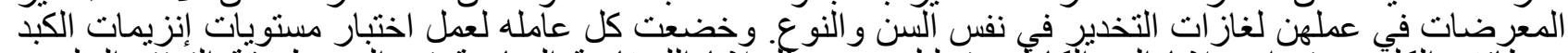

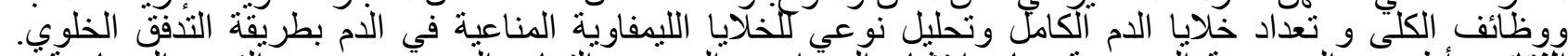

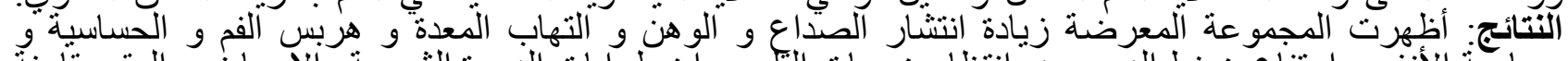

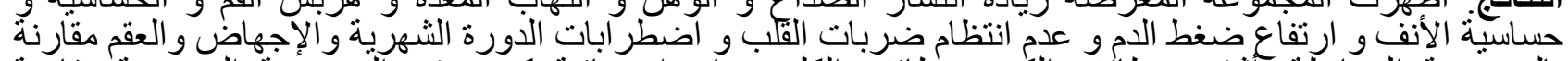

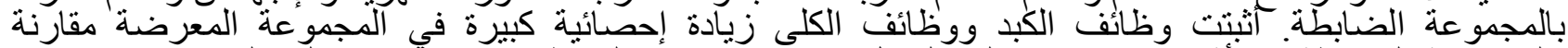

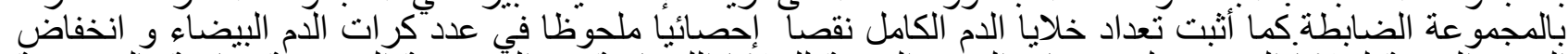

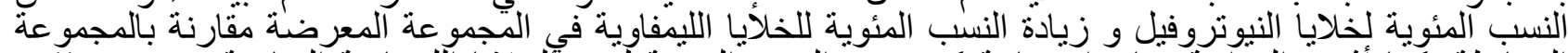

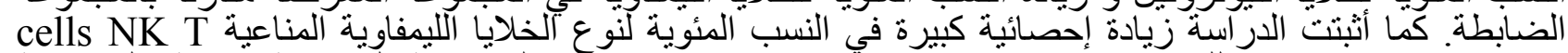

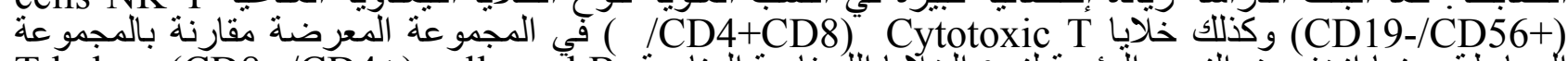

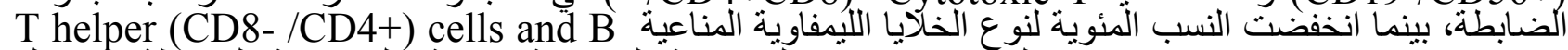

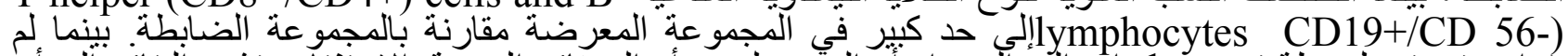

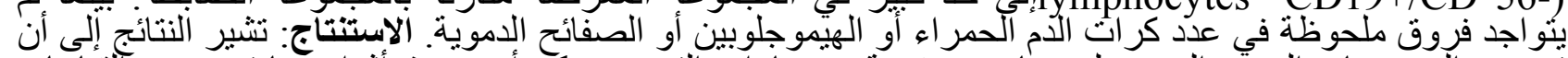

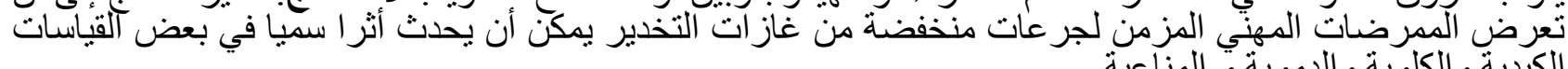

\footnotetext{
1 قسم الطب الثر عي و السموم الإكلينيكية 2

3 قسم الميكروبيولوجيا الطبية و علم المناعة كلية الطب جامعة عين شمس الطبية علر
} 